\title{
Nutrient composition and digestibility of taro leaf in the diets of chicken and effects on the meat quality
}

\begin{abstract}
Introduction: the high cost of cereals and protein supplements and uncertainty about their sustainable supply for poultry pressed the need to search for other potential non-conventional feed sources which are relatively less used for human consumption. For stopping this problem the inclusion of taro leaf meals in poultry ration may supply high nutrients for the consumers because taro is multipurpose crop for food and feed sources. Taro leaf is rich in proteins and can be of supplementary protein, carotene and trace minerals in chicken diets. To achieve maximum efficiency in meat quality and production, properly balanced ration is a pre-requisite and taro could be possible alternative feed ingredients in this study.
\end{abstract}

Objective: This study was conducted to evaluate the feeding value of taro leaf in broiler rations which was conducted at Debre Zeit Agricultural Research Center.

Method and analysis: The study was carried out using four treatments in which the treatments were inclusion of TL at $0 \%\left(\mathrm{~T}_{1}\right), 3 \%\left(\mathrm{~T}_{2}\right), 5 \%\left(\mathrm{~T}_{3}\right)$ and $7 \%\left(\mathrm{~T}_{4}\right)$. The analysis undertaken in this study was feed DM, Crude Fiber (CF), Total Ash (TA), Ether Extract (EE), Crude Protein (CP) and functional properties (WHC, WA, WSI and WAI) of feed offered. The nutritional composition of chicken meat and cost benefit analysis were also evaluated to see the overall benefit of feeding taro. A total of eighty day-old Cobb500 broiler chicks were used for the study and lasted 56days. At the end of the experiment, four birds were randomly taken from each pen and slaughtered for nutrient composition and protein quality analysis.

Results: The result obtained from the study shows that variability was found as taro leaf level increase and from cost and benefit analyses of the study, taro leaf meal is cost effective meal when used as replacement of expensive and conventional meal in broilers rations

Conclusion: Therefore, the present study encourage using taro leaf meal as a good source of nutrients for broilers like other tropical leaves

Keywords: chicken, meat quality, nutrient composition, taro leaf
Volume 7 Issue 3 - 2017

\author{
Melese Temesgen,' Negussie Retta, ${ }^{2}$ Etalem \\ Tesfaye $^{3}$ \\ 'Department of Food Science, Haramaya University, Ethiopia \\ ${ }^{2}$ College of Natural Sciences, Addis Ababa University, Ethiopia \\ ${ }^{3}$ Ethiopian Institute of Agricultural Research, Debre Zeit \\ Agricultural Research Center, Ethiopia
}

Correspondence: Melese Temesgen, Department of Food Science, Haramaya University, P.O.Box I38, Ethiopia, Email melese2b@gmail.com

Received: October 25, 2016 | Published: November 09, 2017
Abbreviations: CF, crude fiber; TA, total ash; EE, ether extract; $\mathrm{CP}$, crude protein; $\mathrm{BW}$, body weight; ADG, average daily gain; WSI, water solubility index; WHC, water holding capacity; ME, metabolizable energy; PER, protein efficiency ratio; DM, dry matter; PER, protein efficiency ratio; PDCAAS, protein digestibility corrected amino acid score

\section{Introduction}

In Ethiopia, in highly populated areas where it may be complex to continue agronomic activities, subsistence poultry can be the best alternative form of income resources, plays a significant role in family nutrition and above all, smallholder poultry provide a good opportunity to address poverty alleviation. ${ }^{1}$ However, scarcity of conventional feedstuffs and food insecurity problems by rapidly increasing population growth are the most aggravating factors at present (FAO, 2014). Most of the population in Ethiopia depends on cereals as stable foods which are also required for poultry feeding. ${ }^{2}$ This means, it is difficult to use cereals for poultry with having human food insecurity burden and replacing expensive cereals and less available agro-industrial by-products by unconventional source of raw materials, which are less exploited by man, is one of the solutions to reduce cost of production and contribute to increased supply of animal protein to rich of poor people's. ${ }^{3,4}$ Diets formulated on a least cost basis are vital and essential. It is generally assumed that improvements in alternative feed resources utilization will be associated with increased rate of productivity and product quality. ${ }^{5}$ However, in Ethiopia this strategy is not practiced because of the less characterization of nonconventional feed sources from rural areas rather dependent on high costs of conventional feed ingredients (maize, soybean and others), many of are utilized primarily in the human food and industrial input application (FAO 2011). This elevates the prices of the products like egg and chicken meat. Thus, high cost of cereals and protein supplements and uncertainty about their sustainable supply pressed the need to search for other potential non-conventional feed sources which are relatively less used for human consumption.

To bridge the gap and tackling the problems, inclusion of taro leaf meals (TLM) in the diets of chicken may brought products rich in essential nutrients for the consumers. The idea of replacing soybean by TL up to $10 \%$ is very important to improve nutrient density and utilization because TL is low in fibre and inhibitors. ${ }^{6}$ Taro leaves can be harvested from plants grown for tubers any time during the season and used as animal feed. Harvesting taro leaves do not affect tuber 
yield rather frequent harvesting increases the leaf yield. Taro leaf is rich in proteins and can be of supplementary protein, carotene and trace minerals in chicken diets. Moreover, most of poultry diets are made of cereals and lack the most important amino acids for humans such as lysine, threonine, the sulphur-bearing amino acids (methionine and cysteine) and occasionally tryptophan unless supplemented in the ration. However, the above mentioned amino acids are very expensive and beyond the rich of poultry farmers. Since this is great problem in nutrition and that is why important to identify alternative high quality protein feed ingredients that contains most of essential amino acids

To achieve maximum efficiency in meat quality and production performance, properly balanced ration is a pre-requisite and taro could be possible alternative feed ingredients in this regard in the poultry industry. Therefore, the present study was designed to address the research question. Does feeding taro leaf meal improve the product and quality of chicken.

\section{Objectives}

\section{General objective}

The general objective of the study is to investigate whether taro leaf could improve the nutrient composition and digestibility of chicken diets and meat essential nutrients.

\section{Specific objectives}

i. To evaluate nutrient (\% DM basis), mineral, anti-nutritional composition and functional properties of different levels of taro leaf meal (TLM)

ii. To evaluate dry matter intake, protein intake, digestibility, protein efficiency, body weight change and dry matter conversion efficiency of broilers fed ration containing different levels of taro leaf meal (TLM)

iii. To determine nutrient composition of chicken meat after use of taro leaf meal

\section{Materials and methods}

\section{Sample source and study sites}

Taro (Colocasia esculenta L.) leaf: boloso-1 variety was harvested at 7 months of age from Areka Agricultural Research Center (AARC) and brought to Addis Ababa University, Ethiopia. The leafs were prepared as powder and then brought to Debre Zeit Agricultural Research Center (DZARC) where the broiler experiment was conducted where located at an altitude of 1900 meters above sea level, at $8044^{\prime} \mathrm{N}$ latitude and 380 38'E longitude and $47 \mathrm{~km}$ east of Addis Ababa,

\section{Samples preparation and treatment formulation}

The harvested fresh leaves were twigged the veins and dried in shade room by spreading the leaflets thinly on mesh tied on wood beds for 4 days. The dried samples were powdered using stainless steel hammer mill to powder particle size of $1.6 \mathrm{~mm}$, packaged in polythene bags and stored in cool dry place until to formulate the TL and used for various feed chemical analyses.

The major feed ingredients were mixed based on feed formulation recipe and carried out for various chemical composition analysis of determined. Four treatment rations were formulated containing TL at levels of $0 \%\left(\mathrm{~T}_{1}\right), 3 \%\left(\mathrm{~T}_{2}\right), 5 \%\left(\mathrm{~T}_{3}\right)$ and $7 \%\left(\mathrm{~T}_{4}\right)$. Taro leaf was included at three levels in the rations to substitute soybean up to $7 \%$ as protein source in broiler diets. The complete ration was formulated from maize, nougseed cake, wheat middling, soybean cake, TL and other minor ingredients of vitamin premix, salt, limestone, methionine and lysine. The formulation was using appropriate feed formulation program to be nearly isocaloric and isonitrogenous with metabolizable energy (ME) content of $3000 \mathrm{kcal} / \mathrm{kg}$ and crude protein (CP) content of $22 \%$ for the starter phase (1 to 28 days of age) and ME content of $3200 \mathrm{kcal} / \mathrm{kg}$ and $\mathrm{CP}$ content of $20 \%$ for the finisher phase (29 to 56days of age) to meet the nutrient requirements (Leeson and summers, 2005).

\section{Management of experimental birds}

Eighty unsexed a-day old broiler chicks were randomly assigned to four dietary treatments as observation trial in a completely randomized design experiment, thus having 20 chicks per treatment. The birds were vaccinated against Newcastle and Infectious Bursal Disease (Gumboro) at the recommended age of vaccination. Other health precautions and sanitary measures were also being taken throughout the study period. Before the commencement of the actual experiment, watering and feeding troughs were thoroughly cleaned, disinfected and sprayed against external parasites. The chicks were brooded using 250 watt infrared electric bulbs with gradual height adjustment as sources of heat and light in a deep litter house covered with sawdust litter material. Feed was offered twice a day and clean tap water was available all the time throughout the experiment.

\section{Measurement of experimental birds}

The experimental period lasted 56days during which the amount of feed consumed was determined as the difference between the feed offered and refused. Feed offered and refused was sampled daily per pen and pooled per treatment for the entire experimental period for chemical analysis. The feed protein intake was calculated as percentage $\mathrm{CP}$ of experimental feed sample multiplied by feed consumed per birds to get true protein intake. For feed and faecal nitrogen mass balance, known mass of faecal samples were taken from each pen. Faecal dropped per birds were calculated as the amount of faecal dropped divided by number of birds. The final mass of faecal dropped was calculated as percentage faecal CP multiplied by faecal dropped per birds to get true faecal dropped. Then true protein intake and faecal dropped were used to calculate feed protein digestibility. For body weight (BW) change record, chicks were weighed weekly and the initial and final weights were used to estimate weight gains. Average daily gain (ADG) was calculated as BW change divided by the number of experimentaldays (56days). Prior to weighing, chicks were fasted overnight. To determine protein efficiency ratio, total true protein intake of feed and birds weight gain changes were used. At the end of the experiment, 2 randomly selected birds from each treatment was starved for 12 hours before slaughter and slaughtered by severing the neck then dry de-feathered by hand plucking. Birds were eviscerated and carcass cuts were taken for nutrient composition and protein quality.

\section{Laboratory analysis}

Samples of feed offered and pooled refusal samples from the respective treatments were analyzed for crude fiber $(\mathrm{CF})$, total ash (TA), ether extract (EE) and $\mathrm{CP}$ using the AOAC reference methods. ${ }^{8}$ The functional properties of feeds such as water absorption index 
(WAI) were determined according to Anderson. ${ }^{9}$ The water solubility index (WSI) in percentage was calculated as a ratio of dry residue to the original mass used to estimate $\mathrm{WAI}^{9}$ and the water holding capacity (WHC) of feed samples were estimated (AACC method 56-20). ${ }^{8}$ Metabolizable energy (ME) content of the experimental diets was determined according to $\mathrm{Wiseman}^{10}$ as: $\mathrm{ME}(\mathrm{kcal} / \mathrm{kg}$ $\mathrm{DM})=3951+54.4 \mathrm{EE}-88.7 \mathrm{CF}-40.80 \mathrm{Ash}$. Minerals of Na, K, Fe, Zn, Cu and $\mathrm{P}$ were analyzed by using atomic absorption spectrophotometer. ${ }^{8}$ Total phenolic compound was analyzed using Biswas et al. ${ }^{11}$ The AOAC method was used to determine the oxalate, tannin and phytate contents of feed sample. After slaughter, carcass cuts of breast and thigh muscles without skin were taken, freeze dried and homogenized and has been tested for proximate content (AOAC Official Method 925.10). For the other protein quality parameters analysis, digestibility was calculated as apparent and true digestibility. ${ }^{12}$ Protein efficiency ratio (PER) was calculated based on the weight gain of birds divided by intake of a particular food protein during the test period. ${ }^{13}$ Protein digestibility corrected amino acid score (PDCAAS) was determined from protein digestibility multiplied by amino acid score. ${ }^{13}$ Amino acid score was measured as gram of essential amino acid in sample divided by mille gram of reference essential amino acid.

\section{Statistical analysis}

The statistical analysis was conducted to examine the effects of taro leaf meal on feed composition, functional properties, body weight gain, digestibility, protein efficiency ratio and finally chicken meat composition analysis Data were analyzed using the general linear model procedures of Statistical Analysis Systems software ${ }^{14}$ with the model containing treatments. Probability values $\leq 0.05$ were considered significant.

\section{Results and discussions}

The dry matter (DM) content (\%) of rations from different levels of taro leaf containing diets ranged from $93.33 \pm 0.02$ to $93.39 \pm 51.05$ and showed no difference among the treatments (Table 1). The values resulted from the present study was in a similar range with the values of DM\% reported by Etalem et al., ${ }^{15}$ for Moringa oliefera leaf meal containing diets.

Table I Nutrient composition (\% DM basis) and functional properties of treatments ration containing different level of taro leaf (TL)

\begin{tabular}{|c|c|c|c|c|}
\hline \multirow{2}{*}{ Parameters } & \multicolumn{4}{|l|}{ Treatments } \\
\hline & $\mathbf{T}_{1}$ & $\mathbf{T}_{2}$ & $\mathbf{T}_{3}$ & $\mathbf{T}_{4}$ \\
\hline DM & $93.33 \pm 0.02^{\mathrm{a}}$ & $93.35 \pm 0.02^{\mathrm{a}}$ & $93.34 \pm 5.90^{\mathrm{a}}$ & $93.39 \pm 5.05^{\mathrm{a}}$ \\
\hline $\mathrm{CP}$ & $21.30 \pm 0.02^{\mathrm{a}}$ & $21.27 \pm 0.05^{\mathrm{a}}$ & $21.62 \pm 0.05^{\mathrm{a}}$ & $21.77 \pm 0.06^{\mathrm{a}}$ \\
\hline CF & $8.87 \pm 0.04^{a}$ & $7.81 \pm 0.05^{a}$ & $6.19 \pm 0.07^{b}$ & $6.44 \pm 0.05^{b}$ \\
\hline EE & $4.5 \mathrm{I} \pm 0.0 \mathrm{I}^{\mathrm{ab}}$ & $4.15 \pm 0.04^{a}$ & $4.23 \pm 0.06^{a}$ & $4.34 \pm 0.06^{a}$ \\
\hline Ash & $10.96 \pm 0.04^{\mathrm{ab}}$ & $12.33 \pm 0.05^{\mathrm{a}}$ & $|2.6| \pm 0.07^{a}$ & $12.89 \pm 0.05^{\mathrm{a}}$ \\
\hline Carbohydrate & $55.36 \pm 0.03^{\mathrm{ab}}$ & $54.44 \pm 0.04^{\mathrm{a}}$ & $55.35 \pm 0.08^{a}$ & $54.86 \pm 0.05^{\mathrm{a}}$ \\
\hline ME & $2962.407 \pm 0.02^{d}$ & $2980.95 \pm 0.03^{c}$ & $3117.57 \pm 0.07^{a}$ & $3116.57 \pm 0.06^{b}$ \\
\hline$A B I$ & $1.53 \pm 0.04^{\mathrm{a}}$ & $1.45 \pm 0.03^{\mathrm{a}}$ & $\mathrm{I} .4 \mathrm{I} \pm 0.03^{\mathrm{ab}}$ & $1.42 \pm 0.07^{\mathrm{ab}}$ \\
\hline SBI & $19.63 \pm 0.04^{\mathrm{ab}}$ & $20.68 \pm 0.07^{a}$ & $20.30 \pm 0.02^{\mathrm{a}}$ & $20.98 \pm 0.06^{\mathrm{a}}$ \\
\hline HDC & $0.98 \pm 0.04^{\mathrm{a}}$ & $0.83 \pm 0.02^{\mathrm{ab}}$ & $0.92 \pm 0.02^{\mathrm{a}}$ & $0.90 \pm 0.05^{a}$ \\
\hline
\end{tabular}

a-d Means in the same row with a common superscript did not differ significantly ( $P>0.05)$; DM, dry matter; $C P$, crude protein; $C F$, crude fiber; $E E$, ether extract; $\mathrm{ME}$, metabolizable energy; $\mathrm{T}_{1}$, ration containing $0 \% \mathrm{TL} ; \mathrm{T}_{2}$, ration containing $3 \% \mathrm{TL} ; \mathrm{T}_{3}$, ration containing $5 \% \mathrm{TL} ; \mathrm{T}_{4}$, ration containing $7 \% \mathrm{TL} ; \mathrm{TL}$, taro leaf; $\mathrm{ABI}$, water absorption index; $\mathrm{SBI}$, water solubility index and $\mathrm{HDC}$, water hydration capacity

\section{Crude protein content}

As presented in Table 1, the CP content in the study varied from $21.27 \pm 0.05$ to $21.30 \pm 0.02$ and there were no difference among the treatments. From the study, the $\mathrm{CP}$ was a little high in $\mathrm{T}_{4}$. Therefore, in order to consider taro leaf as a protein sources the inclusion level should be considered and as increasing inclusion level of taro leaf, the $\mathrm{CP}$ was also consistently increased from the obtained results.

\section{Crude fiber content}

The CF content (\%) in the rations (Table 1) from the different levels of TL differ significantly $(\mathrm{P}<0.05)$. A lower value of CF\% (6.19 \pm 0.07 , $6.44 \pm 0.05)$ was observed in $\mathrm{T}_{3}$ and $\mathrm{T}_{4}$, respectively than $\mathrm{T}_{1}(8.87 \pm$ $0.04)$ and $\mathrm{T}_{2}(7.81 \pm 0.05)$. This might be due to the presence of soluble and digestible fibers in taro. ${ }^{16}$ Also it was noted that taro leaf is low in insoluble fiber content and the fiber in taro is easily soluble and digestible. ${ }^{17}$ Therefore, feed with low fiber like TL, is desirable for digestibility and improve the bulkiness of the feed. In contrary, the high insoluble dietary fiber intake is often associated with slower rate of passage and may inhibit optimal digestion. ${ }^{18}$ Therefore, the present study encourage using TL as a good source of digestible fiber for broilers like other tropical leaves ${ }^{19}$ at inclusion level of 5-7\%. 


\section{Ether extract}

The ether extract content (\%) of the treatment rations ranged from $4.15 \pm 0.04$ to $4.51 \pm 0.01$ (Table 1). From the present study, the results showed a non-significant difference $(\mathrm{P} \geq 0.05)$ among the treatments. However, the ether extracts content of $\mathrm{T}_{1}$ composed little highest and the lowest value obtained in $\mathrm{T}_{2}$. Therefore, the results from the study suggest that addition of taro leaf up to $7 \%$ did not affect the fat content highly. The result of the present study was agreed with the reports of different researchers who reported ether extract content ranged from 4.22 to 4.98 leaf meals made of moringa, cassava and prosop is for chicken ration. ${ }^{14,20-22}$

\section{Total ash}

The total ash content (\%) (Table 1) in the treatments was ranged from $10.96 \pm 0.04$ to $12.89 \pm 0.05$ and did not differ significantly $(\mathrm{P}>0.05)$. The ash contents from the study were above the range of 12.43 to $8.45 \%$ as reported by Etalem T et al., ${ }^{15}$ and other authors ${ }^{23,24}$ on moringa containing broilers feed. This might be due to taro contains higher ash than moringa and leaf meal formulated from taro showed higher cash values.

\section{Carbohydrate and metabolizable energy}

The utilizable carbohydrate content (\%) in different rations ranged from $54.44 \pm 0.04$ to $55.36 \pm 0.03$ (Table 1). The carbohydrate content from the study did not differ significantly $(\mathrm{P}>0.05)$. The result from this study revealed that the carbohydrate contents did not affected by addition of taro leaf and that might be taro leaf did not supplied high carbohydrate source and the main aim of inclusion of taro leaf in this study was as alternative protein feed ingredients. The metabolizable (ME) energy content $(\mathrm{kcal} / \mathrm{kg})$ of the experimental diets is presented in (Table 1). The ME value in different samples differs significantly $(\mathrm{P}<0.05)$ and ranged from $2962.407 \pm 0.02$ in $\mathrm{T}_{1}$ to $3117.57 \pm 0.07$ in $\mathrm{T}_{3}$. The result from the study examined $\mathrm{T}_{3}$ obtained a higher energy value followed by $\mathrm{T}_{4}$ than that of $\mathrm{T}_{1}$. The metabolizable energy from the study was less than the values $(3247 \mathrm{kcal} / \mathrm{kg})$ reported by Etalem et al. ${ }^{15}$ conducted on Moringa oleifera leaf meal. Therefore the energy content was more consistent in taro leaf meal than in control and this might be associated with high ash contents of the taro leaf meal

\section{Water absorption index}

The highest value in absorption index (ABI) of feed rations was $1.53 \pm 0.04$ for ration formulated from control feed and the lowest was $1.41 \pm 0.03$ in DM basis for ration formulated from taro leaf at $5 \%$ (Table 1). However, the ABI value of rations decreased in TL and this may be related to the degree of leaf starch fragmentation. In agreement with this general reality, due to smaller starch fragments of taro leaf decreased the ABI of the feeds, because ABI is related with starch size and the larger starch fragments have high ABI and vise verse..$^{25,26}$ Therefore, feeds with low water absorption index are desirable as the rations would absorb less water and resulting in high nutrient density ${ }^{27}$ The results from this study were in agreement with the above findings and taro leaves from this study were recommended for chicken diets. The study have shown that the inclusion of taro leaf up to $7 \%$ in a broiler diet added some positive effects on low water absorption capacity for a better diet density and consequent effect on body weight gain and growth.

\section{Solubility indexes}

The SBI of treatments ration in this study was ranged from
$19.63 \pm 0.043$ to $20.98 \pm 0.06$ (Table 1 ) and was not showed a significant ( $>0.05$ ) difference among the treatments in the present study. As the result obtained from this study, it can be predicted that rations formulated from taro leaf had a high SBI than the control feed. This increase in SBI for the diets might be again associated with smaller starch size in taro leaf. These findings were similar with the work of different researchers ${ }^{28-30}$ who reported smaller size starch fragments as it has the tendency to become soluble after hydration and increased SBI. Also, other researchers ${ }^{31-33}$ reported more on SBI. The study have shown that the inclusion of taro leaf up to $7 \%$ in a broiler diet added some positive effects on high solubility indexes for a better diet formulation.

\section{Water hydration capacity}

The WHC in this study ranged from $0.83 \pm 0.02$ to $0.98 \pm 0.04$ and did not showed a significant ( $\mathrm{p} \geq 0.05$ ) difference among the treatments. Previous studies also provided evidence that $\mathrm{WHC}$ was related to the degree of starch size and starch fragmentation. ${ }^{34}$ This observation is in harmony with the smaller starch size, the more hydration capacity and solubility indexes for better feed diet formula and mixing ability of ingredients. ${ }^{32}$

The $\mathrm{mg} / 100 \mathrm{~g}$ values in $\mathrm{DM}$ basis of $\mathrm{Na}, \mathrm{K}, \mathrm{Fe}, \mathrm{Ca}, \mathrm{Zn}, \mathrm{Cu}$ and $\mathrm{P}$ were presented in Table 2. The mg/100g Na, K, Fe, Ca, Zn, Cu and $P$ ranged from $4.257 \pm 0.03$ to $6.213 \pm 0.03,10.15 \pm 0.0$ to $19.63 \pm 0.03$, $0.166 \pm 0.04$ to $0.278 \pm 0.03,5.11 \pm 0.02$ to $7.98 \pm 0.04,4.46 \pm 0.06$ to $8.996 \pm 0.05,3.423 \pm 0.03$ to $3.44 \pm 0.04$ and $58.07 \pm 0.02$ to $59.09 \pm 0.06$ of values, respectively. The $\mathrm{mg} / 100 \mathrm{~g}$ of $\mathrm{K}, \mathrm{Fe}$ and $\mathrm{Zn}$ values among the treatments were in the order of $\mathrm{T}_{4}>\mathrm{T}_{3}>\mathrm{T}_{2}>\mathrm{T}_{1}$ and in this study it revealed that TL in the ration was a good way in enriching the mineral supply of feeds mainly with $\mathrm{K}, \mathrm{Fe}$ and $\mathrm{Zn}$ levels but with low level in $\mathrm{Ca}$ and $\mathrm{P}$ contents. Therefore, the obtained results encourage the use of taro leaf, which meant that a ration with more minerals containing formula is good to meet requirements for minerals. ${ }^{35}$

The content of phenols, oxalate, tannin, and phytate in the treatment rations differ significantly $(\mathrm{p}<0.05)$ among the treatments and ranged from $1.68 \pm 0.04$ to $1.89 \pm 0.03,0.16 \pm 0.03 \pm 0.05$ to $0.19 \pm 0.03$, $0.101 \pm 0.03$ to $0.13 \pm 0.04$ and $0.170 \pm 0.05$ to $0.192 \pm 0.03 \mathrm{~g} / 100 \mathrm{~g}$, respectively (Table 2). From the present study, the ration containing TL had a better total phenols and lower anti-nutritional contents of oxalate, tannin and phytate. This could imply that the inclusion of TL in the ration may not hamper the feed intake and feed utilization of birds for appreciated growth rate because of lower anti-nutritional factors and better nutrient promoting factors such as phenolic substance. ${ }^{21}$ In animal feeds the presence of high anti-nutritional factors can decrease feed intake and acceptability of feed nutrients which resulted in poor growth $^{36,37}$ Nworgu. With this context for proper nutrient utilization of feed and appreciated growth rate in chicks, it is vital to reduce the nutrient limiting factors to through preparation and processing. Condensed tannin and other anti-nutritional factors can be reduced during thermal processing and boiling Prajapati et al. ${ }^{38}$

Therefore, it is important to apply different methods of preparation and cooking that could reduce the risk of absorbing excess antinutritional compound when consumed as part of the diet. Therefore, the present study provided an over view of improved processing methods as good ways of reducing the most dominant anti-nutritional components in taro leaf samples and most of the samples contained low anti-nutritional substances when subjected with curd processing. These results were in line with the findings of Abeke et al. ${ }^{39}$ who found that the processing (cooking) method had a significant improvement 
on the mineral content that could increased the performance of chicks. The increase in the performance of chicks might be happened due to intake of low anti-nutritional factors in the ingredients. ${ }^{40}$ As demonstrated in Table 3, DM intake, body weight change, average daily growth and dry matter conversion efficiency of broilers fed ration containing different levels of TL differ significantly $(\mathrm{P}<0.05)$.

Table 2 Mineral and anti-nutritional $(\mathrm{mg} / \mathrm{l00g})$ treatments containing different level of taro leaf $(\mathrm{TL})$

\begin{tabular}{|c|c|c|c|c|}
\hline \multirow{2}{*}{ Parameter } & \multicolumn{4}{|l|}{ Treatment } \\
\hline & $\mathbf{T}_{1}$ & $\mathbf{T}_{2}$ & $T_{3}$ & $\mathbf{T}_{4}$ \\
\hline $\mathrm{Na}$ & $6.21 \pm 0.03^{\mathrm{a}}$ & $4.74 \pm 0.04^{b}$ & $4.67 \pm 0.02^{\mathrm{b}}$ & $4.25 \pm 0.03^{b}$ \\
\hline K & $10.15 \pm 0.0^{c}$ & $15.33 \pm 0.04^{b}$ & $19.41 \pm 0.02^{\mathrm{a}}$ & $19.63 \pm 0.03^{a}$ \\
\hline $\mathrm{Fe}$ & $0.16 \pm 0.04^{b}$ & $0.26 \pm 0.03^{\mathrm{a}}$ & $0.27 \pm 0.02^{\mathrm{a}}$ & $0.28 \pm 0.03^{a}$ \\
\hline $\mathrm{Ca}$ & $7.98 \pm 0.043^{\mathrm{a}}$ & $5.6 \pm 0.03^{b}$ & $5.11 \pm 0.02^{b}$ & $5.112 \pm 0.05^{b}$ \\
\hline Zn & $4.46 \pm 0.06^{b c}$ & $5.46 \pm 0.03^{b}$ & $7.66 \pm 0.02^{\mathrm{ab}}$ & $8.99 \pm 0.05^{a}$ \\
\hline $\mathrm{Cu}$ & $3.44 \pm 0.04^{a}$ & $3.43 \pm 0.03^{\mathrm{a}}$ & $3.42 \pm 0.03^{a}$ & $3.42 \pm 0.03^{\mathrm{a}}$ \\
\hline$P$ & $59.09 \pm 0.06^{\mathrm{a}}$ & $58.07 \pm 0.02^{\mathrm{ab}}$ & $58.90 \pm 0.05^{\mathrm{ab}}$ & $58.99 \pm 0.03^{\mathrm{ab}}$ \\
\hline Phenols & $1.68 \pm 0.04^{\mathrm{ab}}$ & $1.88 \pm 0.032^{\mathrm{a}}$ & $1.88 \pm 0.04^{a}$ & $1.89 \pm 0.03^{\mathrm{a}}$ \\
\hline Oxalate(g/l00g) & $0.18 \pm 0.05^{a}$ & $0.18 \pm 0.02^{a}$ & $0.16 \pm 0.03^{\mathrm{ab}}$ & $0.19 \pm 0.03^{a}$ \\
\hline Tannin $(\mathrm{g} / \mathrm{l} 00 \mathrm{~g})$ & $0.13 \pm 0.04^{\mathrm{ab}}$ & $0.11 \pm 0.02^{b}$ & $0.11 \pm 0.04^{b}$ & $0.10 \pm 0.03^{a}$ \\
\hline Phytate $(\mathrm{g} / 100 \mathrm{~g})$ & $0.170 \pm 0.05^{\mathrm{ab}}$ & $0.192 \pm 0.03^{\mathrm{a}}$ & $0.192 \pm 0.04^{a}$ & $0.175 \pm 0.03^{\mathrm{ab}}$ \\
\hline
\end{tabular}

a-c Means in the same row with a common superscript did not differ significantly $(P>0.05) ; T_{1}$, ration containing $0 \% T L ; T_{2}$, ration containing $3 \% T L ; T_{3}$, ration containing $5 \% \mathrm{TL} ; \mathrm{T}_{4}$, ration containing $7 \% \mathrm{TL} ; \mathrm{TL}$, taro leaf

Table 3 Dry matter intake, body weight change, daily growth and dry matter conversion efficiency of broilers fed ration containing different levels of taro leaf (TL)

\begin{tabular}{|c|c|c|c|c|}
\hline \multirow{2}{*}{ Parameters } & \multicolumn{4}{|l|}{ Treatment } \\
\hline & $\mathbf{T}_{1}$ & $\mathbf{T}_{2}$ & $\mathbf{T}_{3}$ & $\mathbf{T}_{4}$ \\
\hline DMI & $76.33 \pm 0.32$ & $74.25 \pm 0.45$ & $82.179 \pm 0.56$ & $79.192 \pm 0.54$ \\
\hline IBW( g/bird) & $43.5 \pm 0.45$ & $42.95 \pm 0.56$ & $42.25 \pm 0.54$ & $40.56 \pm 0.21$ \\
\hline FBW( g/bird) & $1106 \pm 0.65$ & $1010.632 \pm 0.23$ & $1279.658 \pm 0.32$ & $1324.503 \pm 0.34$ \\
\hline BWC( g/bird) & $1062.5 \pm 0.67$ & $967.682 \pm 0.65$ & $1237.408 \pm 0.45$ & $1283.943 \pm 0.34$ \\
\hline ADG & $18.899 \pm 0.43$ & $18.662 \pm 0.23$ & $25.283 \pm 0.34$ & $29.534 \pm 0.34$ \\
\hline DMCE & $1.28 \pm 0.43$ & $1.378 \pm 0.45$ & $1.511 \pm 0.56$ & $2.612 \pm 0.45$ \\
\hline
\end{tabular}

TL, taro leaf; $\mathrm{T}_{\text {, }}$, ration containing $0 \% \mathrm{TL} ; \mathrm{T}_{2}$, ration containing $3 \% \mathrm{TL} ; \mathrm{T}_{3}$, ration containing $5 \% \mathrm{TL} ; \mathrm{T}_{4}$, ration containing $7 \% \mathrm{TL}$; $\mathrm{DMI}$, dry matter intake; IBW, initial body weight; FBW, final body weight; BWC, body weight change; ADG, average daily growth and DMCE, dry matter conversion efficiency

The DM intake ( $\mathrm{g} / \mathrm{bird})$ for chicks in $\mathrm{T}_{3}$ had the greater value $(82.179 \pm 0.56)$ while the smaller value $(74.25 \pm 0.45)$ in DM intake was found in $T_{2}$. The DM intake increased from $T_{2}$ to $T_{4}$ in all feed groups. Body weight gain and change (g/bird) was in the order of $\mathrm{T}_{4}>$ $\mathrm{T}_{3}>\mathrm{T}_{1}>\mathrm{T}_{2}$. The dietary inclusion of TL in broiler diets depressed feed intake at $3 \%\left(\mathrm{~T}_{2}\right)$ inclusion level compared to the control. However, at $\mathrm{T}_{3}$ and $\mathrm{T}_{4}$ total feed intake was higher and significantly $(\mathrm{P}<0.05)$ different than the control. Therefore BW change was affected by TL level in the study. This showed that the average daily growth was in the order of $\mathrm{T}_{4}>\mathrm{T}_{3}>\mathrm{T}_{1}$. However, the average daily growth for $\mathrm{T}_{2}$ was less than $\mathrm{T}_{1}$. The differences may be related to composition of diet and according to results of the current study, TL inclusion in broilers ration could increase weight gain and daily growth. Consistent with this study improvements were achieved in Moringa oleifera leaf meal up to $20 \%$ level of inclusion replacement for soybean meal. ${ }^{15}$ It was observed that as the level of TL inclusion increased the percentage of 
weight gain and daily growth up to $7 \%$ level of inclusion. Therefore, this study showed that the nutrient status of the experimental diets was adequate for the broiler growth and performance. Concerning the DMCE, had an increasing trend and it was in the order of $\mathrm{T}_{4}>$ $\mathrm{T}_{3}>\mathrm{T}_{2}>\mathrm{T}_{1}$. It is assumed that the presence of anti-nutritionals have attributable effect on depressed feed intake and reduced feed utilization. ${ }^{41-43}$

As presented in Table 4 protein intake in rations containing different levels of TL differ significantly $(\mathrm{p}<0.05)$, but digestibility and protein efficiency ratio did not differ significantly $(p<0.05)$. The protein intake $(\mathrm{g})$ was in the order of $\mathrm{T}_{4}>\mathrm{T}_{3}>\mathrm{T}_{2}>\mathrm{T}_{1}$. The highest protein intake ( $\mathrm{g}$ ) was exhibited in $\mathrm{T}_{4}$ compared to $\mathrm{T}_{1}$. This might be due to $\mathrm{T}_{4}$ diet with high protein level that contained $7 \% \mathrm{TL}$ and that attributed for higher protein intake. Similarly, as reported by Patterson \& Abdulrashid et al., ${ }^{44}$ protein intake, digestible, and nitrogen drop out through fecal increased with protein levels in the diet. Concerning digestibility, there was no significant difference $(\mathrm{P}>0.05)$ in the apparent digestibility, but the true digestibility had greater values in the order of $\mathrm{T}_{4}>\mathrm{T}_{3}>\mathrm{T}_{2}>\mathrm{T}_{1}$. In general, digestibility improved from in the order of $\mathrm{T}_{1}$ to $\mathrm{T}_{4}$. Therefore, $\mathrm{TL}$ is a good digestible alternative feed source than the control feed. The quality of a feed protein depends not only on nitrogen content, but also on their digestibility. ${ }^{45}$

Table 4 Total protein intake, digestibility and protein efficiency ratio of broilers fed ration containing different levels of taro leaf (TL)

\begin{tabular}{lllll}
\hline \multirow{2}{*}{ Parameters } & \multicolumn{4}{l}{ Treatment } \\
\cline { 2 - 5 } & $\mathbf{T}_{1}$ & $\mathbf{T}_{2}$ & $\mathbf{T}_{3}$ & $\mathbf{T}_{4}$ \\
\hline PI (\%) & $469.77 \pm 0.05^{\mathrm{d}}$ & $503.02 \pm 0.05^{\mathrm{c}}$ & $603.12 \pm 0.04^{\mathrm{b}}$ & $1109.92 \pm 0.06^{\mathrm{a}}$ \\
AD (\%) & $99.06 \pm 0.01^{\mathrm{ab}}$ & $99.035 \pm 0.02^{\mathrm{b}}$ & $99.05 \pm 0.02^{\mathrm{b}}$ & $99.22 \pm 0.04^{\mathrm{ab}}$ \\
TD (\%) & $99.6 \pm 0.01^{\mathrm{ab}}$ & $99.625 \pm 0.01^{\mathrm{ab}}$ & $99.645 \pm 0.01^{\mathrm{ab}}$ & $99.685 \pm 0.01^{\mathrm{ab}}$ \\
PER & $1.31 \pm 0.04^{\mathrm{ab}}$ & $1.062 \pm 0.05^{\mathrm{ab}}$ & $1.286 \pm 0.03^{\mathrm{a}}$ & $1.286 \pm 0.07^{\mathrm{a}}$ \\
\hline
\end{tabular}

a-d Means in the same row with a common superscript did not differ significantly ( $P>0.05) ; T L$, taro leaf; $\mathrm{T}_{1}$, ration containing $0 \% \mathrm{TL} ; \mathrm{T}_{2}$, ration containing $3 \% \mathrm{TL} ; \mathrm{T}_{3}$, ration containing $5 \% \mathrm{TL} ; \mathrm{T}_{4}$, ration containing $7 \% \mathrm{TL}$; PI, protein intake;AD, apparent digestibility; TD, true digestibility; PER, protein efficiency ratio $\mathrm{TL}$, taro leaf; $\mathrm{T}_{\text {}}$, ration containing $0 \% \mathrm{TL} ; \mathrm{T}_{2}$, ration containing $3 \% \mathrm{TL} ; \mathrm{T}_{3}$, ration containing $5 \% \mathrm{TL} ; \mathrm{T}_{4}$, ration containing $7 \% \mathrm{TL}$

Digestibility depends on amount of true protein intake and fecal protein out; therefore, the present study revealed that digestibility improved as protein level increased in TL. In general, the result of this study showed that TL contained appreciable amounts of digestible nutrients (protein, fiber and minerals) to promote weight gain and performance. Therefore, the present study answers the questions regarding digestibility of diet and feed intake of broilers affected by the level and nature of protein in feed diets. From previous works, little has been reported concerning the use of taro leaf as feed. From the present study digestibility results would contribute to scale up the use of taro leaf for feed purpose in developing countrie. ${ }^{46}$ The protein efficiency ratio was in the order of $\mathrm{T}_{4}>\mathrm{T}_{3}>\mathrm{T}_{1}$. This might be as a result of high digestible protein in $\mathrm{T}_{4}$ and $\mathrm{T}_{3}$ contributed for marked protein intake and weight gain compared to control feed. However, the protein efficiency ratio of $\mathrm{T}_{2}$ was lowest of all treatments. This, finding was in harmony with results of dietary supplementation of Moringa oleifera on protein efficiency and growth of boilers. ${ }^{47}$

The nutrient content of chicken meat was determined and differs significantly as shown in Table 5 . The breast muscles have better nutrient composition than that of the tight muscles. In both breast and tight muscles the nutrient compositions were in the order of $\mathrm{T}_{4}>\mathrm{T}_{3}>$ $\mathrm{T}_{2}>\mathrm{T}_{1}$ except the crude fiber content. Rations containing increased level of TL had greater values than the controlled feed.

The quality of a feed protein highly depends on the protein composition of final products such as meat. ${ }^{48}$ The present study was consistent with the findings of Melesse et al., ${ }^{49}$ who proved that the quality of protein and amino acid content of feed are known to enhance muscle protein. Therefore, diet formulation based on enriched nutrients mainly protein is clearly superior to improve the nutritional quality of chicken meat. ${ }^{17}$ Also the observation from the present study was in harmony with Kingori, ${ }^{51}$ Opapeju et al. ${ }^{51}$ noted that diet formulation based on high protein would allow the use of alternative protein sources would improve the precision of least-cost diets and reduce nitrogen excretion from chicken operations. Therefore, protein sources are especially limiting factors in chicken feed production and the quality of their end products. ${ }^{52}$ From cost and benefits analyses of the study, taro leaf is cost effective when used as replacement of soybean meal in chicken Table $6 .{ }^{53-56}$

Table 5 Nutrient composition of broiler meat after feeding different level of taro leaf (TL) for 56 days

\begin{tabular}{|c|c|c|c|c|c|c|c|c|}
\hline \multirow{2}{*}{ Chicken meat } & \multicolumn{8}{|l|}{ Treatments } \\
\hline & Control $\left(T_{1}\right)$ Breast & $T_{2}$ Breast & $T_{3}$ Breast & $\mathbf{T}_{4}$ Breast & Control $\left(T_{1}\right)$ Thigh & $\mathbf{T}_{2}$ Thigh & $\mathbf{T}_{3}$ Thigh & $\mathrm{T}_{4}$ Thigh \\
\hline Moisture (\%) & 75.29 & 74 & 76.21 & 74.99 & 75.01 & 69.87 & 76.27 & 75.25 \\
\hline Protein (\%) & 80.87 & 89.36 & 92.68 & 88.62 & 70.67 & 63.14 & 73.08 & 76.8 \\
\hline Fat (\%) & 2.58 & 3.313 & 3.3 & 3.37 & 2.67 & 3.35 & 3.45 & 3.467 \\
\hline Fiber (\%) & 2.56 & 0.67 & 0.07 & 0.027 & 3.238 & 1.211 & 0.113 & 0.07 \\
\hline Ash (\%) & 4.27 & 4.389 & 4.481 & 4.89 & 4.06 & 4.132 & 4.321 & 4.53 \\
\hline Vita $C(\mathrm{mg} / 100 \mathrm{gm})$ & 3.61 & 4.665 & 8.39 & 10.56 & 3.123 & 3.879 & 7.86 & 9.465 \\
\hline
\end{tabular}


Table 6 Cost benefit analysis of feeding taro leaf in broiler production for 56 days

\begin{tabular}{|c|c|c|c|c|}
\hline \multirow{2}{*}{ Cost benefit parameters } & \multicolumn{4}{|c|}{ Treatments(Feed rations) } \\
\hline & $\mathbf{T}_{1}$ & $\mathbf{T}_{2}$ & $\mathbf{T}_{3}$ & $\mathbf{T}_{4}$ \\
\hline \multicolumn{5}{|l|}{ Total benefit parameters } \\
\hline Feed Cost Total (Birr) & $|624.6|$ & 823.55 & 810.85 & 793.05 \\
\hline Feed Intake Total (Kg) & 42.85 & 40.11 & 38.45 & 40.34 \\
\hline Weight Gain (G) & 640 & 580 & 775 & 840 \\
\hline Sale Of Live Chicken Total (Birr) & 3600 & 3400 & 4000 & 4000 \\
\hline Ratio (Total Cost/Wt Gain ) & 2.54 & $\mathrm{I} .42$ & 1.05 & 0.94 \\
\hline Net Profit (Birr) & 1975.39 & 2576.45 & 3189.15 & 3206.95 \\
\hline Profitability Index & 10.97 & 15.16 & 15.95 & 16.03 \\
\hline \multicolumn{5}{|l|}{ Individual benefit parameters } \\
\hline Cost Per Bird (Birr) & 81.23 & 41.18 & 40.54 & 39.65 \\
\hline Intake Per Bird & 2.23 & 2.32 & 2.26 & 2.29 \\
\hline Ratio (Cost/Wt Gain ) & 0 & 17.75 & 17.94 & 17.32 \\
\hline Sale Of Live Chicken(Birr) & 180 & 170 & 200 & 200 \\
\hline Profits Individual(Birr) & 180 & 128.82 & 159.46 & 160.35 \\
\hline
\end{tabular}

\section{Acknowledgments}

None.

\section{Conflict of interest}

Author declares that there is no conflict of interest.

\section{References}

1. Jamroz D. Influence of feed diets on the quality of poultry products. VIII Symposium on Poultry, WPSA, Polanica Zdroj Wroclaw; 2007:12-16.

2. Alemu Yami, Tadelle Dessie. The status of poultry research and development in Ethiopia. Research Bulletin No 4. 1997.

3. Amin I, Cheah SF. Determination of vitamin C, $\beta$-carotene and riboflavin contents in five green vegetables organically and conventionally grown. Malays J Nutr. 2010;9(1):31-39.

4. Silva JHV, Silva EL da, Filho JJ, et al. Energy value and effect of integral mesquite pods Prosopis juliflora (Sw) DC.) meal inclusion in commercial laying hens diets. R Bras Zootec. 2004;31(6):2255-2264.

5. Tion MA, Adeka I. The evaluation of cassava root meal as replacement for maize in broiler diets. In: Proceedings of the $25^{\text {th }}$ Annual Conference, Nigerian Society of Animal Production. Michael Okpara, University of Agriculture, Umudike, Nigeria; 2000.

6. McDonald P, Edward R, Greehalgn JF, et al. Animal Nutrition. 6th ed. Gasport, USA:Ashford Color Press; 2002.

7. Leeson S, JD Summers. Commercial Poultry Nutrition. 3rd ed. Canada:Nottingham University Press; 2005. 398p.

8. Approved Methods of the American Association of Cereal Chemists. 10th ed. AACC Method 44-15A. American Association of Cereal Chemists, St Paul, MN, USA; 2000.

9. Anderson RA. Water absorption and solubility and amylograph characteristics of roll-cooked small grain products. Cereal Chemistry. 1982;59(4):265-269.

10. Wiseman J. Feeding of Non-Ruminant Livestock. London:Butterworth and Co. Ltd; 1987. 228p.

11. Biswas AK, J Shahoo, MK Chatli. A simple UV-vis spectrophtometric method for determination of $\beta$-carotene content in raw carrot, sweet potato and supplemented chicken meat nuggets. LWT-Food Science and Technology. 2011;44(8):1809-1813.

12. Expert consultation on protein quality evaluation. Rome:FAO /WHO; 1993.

13. William Horwitz, George W Latimer. Official Methods of Analysis of the AOAC international. 18th ed. Washington, DC, USA; 2006.

14. SAS Guide to personal computers (Version 9) SAS institute Inc. Science. NC, USA; 2002;84:1130-1137.

15. Etalem T, M Urge, G Animut. Moringa oleifera leaf meal as alternative protein feed ingredient in broilers ration. International Journal of Poultry Science. 2013;12(5):289-297.

16. Adane Tilahun, Shimelis Adamu, Negussie Retta, et al. Effect of processing method on the proximate composition, mineral content and ant-nutritional factors of taro (Colocasia esculenta, L.) grown in Ethiopia. Africa Journal of Food, Agriculture, Nutrition and Development. 2013;34(2):1411-1488. 
17. Dari RL, AM Penz, Kessler Jr, et al. Use of digestible amino acids and the concept of ideal protein in feed formulation for broilers. $J$ Appl Poult Res. 2005;14:195-203.

18. Ten Doeschate RAHM, Scheele CW, Schreurs VVAM, et al. Digestibility studies in broiler chickens: Influence of genotype, age, sex and method of determination. British Poultry Science. 2003;34(1):131-146.

19. Abuye C, Urga K, Knapp H, et al. A compositional study of Moringa stenopetala leaves. East Afr Med J. 2003;80(5):247-252.

20. Agbede JO, Aletor VA. Evaluation of fishmeal replaced with leaf protein concentrate from glyricidia in diets for broiler chicks:effects on performance, muscle growth, hematology and serum metabolites. International Journal of Poultry Science. 2003;2(4):242-250.

21. Mutayoba SK, Dierenfield E, Mercedes VA, et al. Determination of chemical composition and anti-nutritive components for Tanzanian locally available poultry feed ingredients. International Journal of Poultry Science. 2011;10(5):350-357.

22. Girma M, Urge M, Animut G. Ground Prosopis juliflora pods as feed ingredient in poultry diet:effects on nutrient intake, muscle fatty acid composition, sensory quality and hematology of broilers. Pakistan Journal of Nutrition. 2013;11(11):1014-1022.

23. Amaefule KU, Obioha FC. Performance of Pullets Chicks fed raw or processed pigeon pea (Cajanus Cajan) seed meal diets. LRRD. $2005 ; 17(3)$.

24. Olugbemi TS, Mutayoba SK, Lekule FP. Effect of Moringa oleifera inclusion in cassava based diets fed to broiler chickens. International Journal of Poultry Science. 2010;9(4):363-367.

25. Jirarat T, Pasawadee P, Sukruedee Asavasaksakul. Taro Colocasia esculenta (L.) Scott Amylopectin Structure and Its Effect on Starch Functional Properties. Starch. 2007;59(7):342-347.

26. Obatolu VA, Cole AH. Functional property of complementary blends of soybean and cowpeas with malted or un malted maize. Food Chemistry. 2009;70(2):147-153.

27. Ikpeme-Emmanuel CA, Okoi J, Osuchukwu NC. Functional, antinutritional and sensory acceptability of taro and soybean based weaning food. African Journal of Food Science. 2009;3(11):372-377.

28. Colonna P, Tayeb J, Mercier C. Extrusion Cooking. Extrusion cooking of starch and starchy products. USA; 1989. p. 247-319.

29. Ollet AL, Parker R, Smith AC, et al. Macro structural changes during the twin screw extrusion cooking of maize grits. Carbohydrate Polymers. 1990;13:69-84.

30. Sharma SK, Gupta VK. In vitro antioxidant activities of aqueous extract of ficus Bangalensis Linn. Root. International Journal of Biological Chemistry. 2010;4(3):134-140.

31. Achinewhu SC. Effects of fermentation on carbohydrates and fatty acid composition of African oil bean seed (Pentaclethra macrophyella). Food Chemistry. 1986;19(2):105-116.

32. Amadi EN, Barimalaa IS, Omosigho J. Influence of temperature on the fermentation of bambara groundnut (Vigna subterranean) to produce a dawadawa-type product. Plant Foods Hum Nutr. 1999;54(1):13-20.

33. Jones D, Chinnaswamy R, Tan Y, et al. Physicochemical properties of ready-to-eat breakfast cereals. Cereal Food World. 2000;45:164-168.

34. Owusu-Ansah JM, Van-De Voort FR, Stanley DW. Physicochemical changes in corn starch as a function of extrusion variables. Cereal Chemistry. 1993;60(4):319-324.

35. Anjorin TB, Ikokoh P, Okolo S. Mineral composition of Moringa leaves, Pods and seeds from two regions in Abuja, Nigeria. International journal of biology. 2010;12:431-434.
36. Udedibie ABI, Chukwurah OJ, Enyenihi GE, et al. The use of sundried cassava tuber meal, brewers' dried grains and palm oil to simulate maize in the diet of laying hens. Journal of Agricultural Technology. 2012;8(4):1269-1276.

37. Esonu B, Emenalom O, Udedibie A, et al. Performance and blood chemistry of weaner pigs fed raw mucuna (Velvet bean) meal. Trop Anim Prod. 2003;4:49-54.

38. Joh Ar, Djuikwo Vn, Gouado I, Et Al. Nutritional Component Of Some Non-Conventional Leaf Vegetable Consumed In Cameroon. Pakistan Journal Of Nutrition. 2007;6(6):712-717.

39. Abeke FO, Olddel AAS, ekoni II, et al. Effect of duration of cooking of lablab purpureuss Beans on the performance organ weights and hematological parameters of Shika-brown pullet chicks. Journal of Biological Science. 2007;7(3):562-565.

40. Hang DT, Binh LV. Oxalate concentration in taro leaves and pentioles and effect of added calcium on nitrogen and calcium retention in pigs given diets containing $50 \%$ ensiled taro leaves and pentioles. Livestock research for Rural Development. 2013;25(4).

41. Agwunobi LN, Angwukan PO, Cora OO, et al. Studies of the use of Colocasia esculenta (Taro Cocoyam) in the Diets of weaned Pigs. Trop Anim Health Prod. 2002;34(3):241-247.

42. Ndimantang B, Asinobi CO, Obiakor N. The effect of different processing methods on some anti-nutritional factors content of Ede uhie (Xanthosoma sagittifolium) and edeocha (Colocasia esculenta). International Journal of Agriculture and Rural Development. 2006;7(2):7-14.

43. Okereke CO. Utilization of Cassava, sweet potato and Cocoyam meals as dietary sources for poultry. World $J$ of Engineering and Pure and Applied Sci. 2012;2(3):63-68.

44. Abdulrashid M, Agwunobi LN. Taro cocoyam (Colocasia esculenta) Meal as Feed Ingredient in Poultry. Pakistan Journal of Nutrition. 2009;8(5):668-673.

45. Ravindran V, Blair R. Feed resources for poultry production in Asia and the Pacific region. I. Energy sources. World's Poultry Sci J. 1991;47(3):213-231.

46. Fasuyi AO, Dairo FAS, Adeniji AO. Tropical Vegetable (Amaranthus Cruentus) leaf meal as alternative protein supplement in broiler starter diets:Bionutritional evaluation. Journal of Central European Agriculture. 2008;9(1):23-34.

47. Du PL, Lin PH, Yang RY, et al. Effects of dietary supplementation of Moringa oleifera on growth performance, blood characteristics and immune response in broilers. Journal of the Chinese Society of Animal Science. 2007;36(3):135-146.

48. Osek M, Janocha A, Klocek B, et al. Influence of the type of feed protein on the quality of carcasses and poultry meat. In: annual. Sciences. Zoot. 2004;20:229-234.

49. Melesse A, Tiruneh W, Negesse T. Effects of feeding Moringa stenopetala leaf meal on nutrient intake and growth performance of Rhode Island Red chicks under tropical climate. Tropics and subtropics agroecosyst. 2011;14:485-492.

50. Kingori G. The protein and energy requirements of indigenous chicken of Kenya. Egerton University, Kenya; 2004.

51. Opapeju FO, Golian A, Nyachoti CM, et al. Amino acid digestibility in dry extruded-expelled soybean meal fed to pigs and poultry. $J$ Anim Sci. 2006;84(5):1130-1137.

52. Atawodi SE, Mari D, Atawodi JC, et al. Assessment of Leucaena leucocephala leaves as feed supplement in laying hens. African Journal of Biotechnology. 2008;7:317-321. 
53. Official Methods of Analysis of the AOAC international. 16th ed. 4th revised method 944.02. Gaithersburg: The Association; 2000.

54. Meseret Girma, Mengistu Urge, Getachew Animut. Ground Prosopis juliflora pod as feed ingredient in poultry diet:Effects on growth and carcass characteristics of broilers. International journal of poultry sciences. 2011;10(12):970-976.
55. Moyo B, JM Patrick, Arnold H, et al. Nutritional characterization of moringa (Moringa oleifera Lam.) leaves. Afr $J$ Biotechnol. 2011;10(60):12925-12933.

56. Zein Elabdin A, Mukhtar A. Effect of feeding broiler chicks on graded levels of soaked prosopis seeds. Australian journal of basic applied science. 2011;5(7):45-48. 